\title{
Re: Pessary or Surgery for a Symptomatic Pelvic Organ Prolapse, PEOPLE study: A Multicenter Prospective Cohort Study
}

\author{
Jack Juckes ${ }^{1}$ \\ ${ }^{1}$ Queen Mary University of London
}

October 17, 2021

\section{Hosted file}

Letter manuscript.docx available at https://authorea.com/users/441524/articles/542007-repessary-or-surgery-for-a-symptomatic-pelvic-organ-prolapse-people-study-a-multicenterprospective-cohort-study 